\title{
A novel rabbit monoclonal antibody platform to dissect the diverse repertoire of antibody epitopes for HIV-1 Env immunogen design
}

\author{
Y Chen ${ }^{1 *}$, M Vaine ${ }^{1}$, X Kong ${ }^{2}$, D Montefiori ${ }^{3}$, S Wang ${ }^{1}, S$ Lu$^{1}$ \\ From AIDS Vaccine 2012 \\ Boston, MA, USA. 9-12 September 2012
}

\section{Background}

The majority of available monoclonal antibodies (mAbs) in the current HIV vaccine field are generated from HIV-1 infected people. In contrast, preclinical immunogenicity studies have mainly focused on polyclonal antibody responses in experimental animals. Although rabbits have been widely used for antibody studies, there has been no report of using rabbit mAbs to dissect the specificity of antibody responses for AIDS vaccine development.

\section{Methods}

Here we report the production of a panel of $12 \mathrm{mAbs}$ from one NZW rabbit that was immunized with a HIV-1 JR-FL gp120 DNA prime and protein boost vaccination regimen.

\section{Results}

These rabbit mAbs recognized a diverse repertoire of epitopes. Besides the traditional highly immunogenic V3 region, these $\mathrm{mAbs}$ recognized several previously underappreciated epitopes in the $\mathrm{C} 1, \mathrm{C} 4$, and $\mathrm{C} 5$ regions. Nine mAbs showed cross-reactivity against gp120s of clades other than clade B. At least three mAbs showed neutralizing activities with various breadth and potency. Increased somatic mutation percentage and long CDR3 were observed with some of the rabbit mAbs. More interestingly, phylogenic tree analysis showed that the heavy chain of $\mathrm{mAbs}$ recognizing the same region on gp120 were segregated into an independent subtree, implicating that these mAbs may derive from the same B cell precursor. Crystal structures of several rabbit mAbs suggested that these rabbit mAbs generated from vaccines mimic the

'University of Massachusetts Medical School, Worcester, MA, USA

Full list of author information is available at the end of the article binding modes of well-characterized human mAbs isolated from infected individuals.

\section{Conclusion}

Therefore, isolation of mAbs from vaccinated rabbits provides us an opportunity to study the evolution and affinity maturation of HIV-1 Env-specific mAbs elicited by candidate AIDS vaccines.

\section{Author details}

${ }^{1}$ University of Massachusetts Medical School, Worcester, MA, USA. ${ }^{2}$ New York University School of Medicine, New York, NY, USA. ${ }^{3}$ Duke University Medical Center, Durham, NC, USA.

Published: 13 September 2012

doi:10.1186/1742-4690-9-S2-P83

Cite this article as: Chen et al:: A novel rabbit monoclonal antibody platform to dissect the diverse repertoire of antibody epitopes for HIV-1 Env immunogen design. Retrovirology 2012 9(Suppl 2):P83.

Submit your next manuscript to BioMed Central and take full advantage of:

- Convenient online submission

- Thorough peer review

- No space constraints or color figure charges

- Immediate publication on acceptance

- Inclusion in PubMed, CAS, Scopus and Google Scholar

- Research which is freely available for redistribution 